ic products upon the interaction with the active forms of oxygen, no adverse effects in case of overdose. In turn, of particular interest, in our view, is the possibility of using unclaimed pharmaceutical industry vegetable raw materials for the correction of oxidative stress in conditions of exposure to adverse environmental factors.

Materials and methods. In experimental conditions the possibility to correct free radical lipid oxidation of rats' organism membranes was studied with the oral introduction of the tincture of herb chickweed that contains the complex of natural antioxidants. The animals were divided into 3 groups and each of them had 20 rats: intact animals which were held in standard conditions of vivarium; the control group in which rats were exposed to heat during forty-five minutes daily; the experimental group in which before the effects of heat animals had a daily oral intake of the tincture of herb chickweed in a dose of $5 \mathrm{ml} / \mathrm{kg}$. The intensity of peroxidation processes was assessed by examining the contents of hydroperoxides lipids, diene conjugates, malonic dialdehyde and the main components of the antioxidant system, (ceruloplasmin, vitamin E) in the liver homogenate animals. The results obtained were subjected to statistical analysis with calculation of parametric criteria Student.

It was found out that in the blood of experimental animals a daily heat exposure during forty-five minutes contributes to the increase of lipid hydroperoxides level (by $18-20 \%$ ), of diene conjugate (by $15-18 \%$ ), and of malonic dialdehyde (by $57-83 \%$ ) against the decrease of antioxidant system activity in the blood of intact animals. The introduction of the tincture of herb chickweed to rats in the conditions of heat exposure contributes to the reliable decrease in the blood of lipid hydroperoxides by $8-16 \%$, of diene conjugates - by $7-20 \%$, and of malonic dialdehyde by $7-26 \%$ in comparison with the rats of the control group. While analyzing the effect of the phytodrug on the activity of the components of antioxidant system it was shown that the level of ceruloplasmin in the blood of animals was reliably higher by $8-21 \%$, of vitamin $\mathrm{E}$ by $5-24 \%$, of catalase by $10-32 \%$ in comparison with the same parameters of the rats of the control group.

So, the application of the tincture of herb chickweed in the conditions of heat exposure of the organism of animals under experiment leads to the stabilization of the processes of peroxidation against the increase of antioxidant system activity.

\title{
REFERENCES
}

Dorovskikh V.A., Borodin E.A., Lee O.N., Simonova N.V., Starberg M.A., Dorovskikh Yu.V. Comparative efficiency of different antioxidants during cold exposure and overheating. Blagoveshchensk; 2016 (in russian).

Dorovskikh V.A., Borodin E.A., Shtarberg M.A., Shtarberg S.A., Egorov K.E. Phospholipids as antiatherosclerotic drugs. In book: Lipoproteins and atherosclerosis. Abstracts of the Symposium devoted to the 110 anniversary from the birthday of academician N.N. Anichkov «Lipoproteins and atherosclerosis». Moscow; 1995: 41-46 (in russian).

Dorovskikh V.A., Tseluyko S.S., Simonova N.V., Anokhina R.A. In the world of antioxidants. Blagoveshchensk, 2012 (in russian).

Landyshev Ju.S., Dorovskikh V.A., Tseluyko S.S., Lazutkina E.L., Tkacheva S.I., Chaplenko T.N. Bronchial asthma. Blagoveshchensk, 2010 (in russian).

Landyshev Ju.S., Dorovskikh V.A., Chaplenko T.N. Drug Allergy. St-Petersburg, 2010 (in russian).

Simonova I.V., Dorovskikh V.A., Simonova N.V., Shtarberg M.A. Non-specific preventive measures against respiratory diseases of nursery age children. Far Eastern Medical Journal 2009; 3:56-58 (in russian).

Simonova N.V. Herb extracts and oxidative stress in the ultraviolet irradiation conditions. Agricultural research Journal 2011; 8:23-26 (in russian).

Simonova N.V., Dorovskikh V.A., Anokhina R.A. Medicinal plants of the Amur region. Blagoveshchensk; 2016 (in russian).

Simonova N.V., Dorovskikh V.A., Shtarberg M.A. Effect of adaptogens of plant origin on the intensity of the processes of peroxidation of lipids of membranes under conditions of ultraviolet irradiation. Far Eastern Medical Journal 2010; 2:112-115 (in russian).

Simonova N.V., Dorovskikh V.A., Simonova N.P. Ultraviolet radiation and oxidative stress. The possibility of phitocorrection. Blagoveshchensk, 2014 (in russian).

Simonova N.V., Dorovskikh V.A., Li O.N., Shtarberg M.A., Simonova N.P. Tincture of medicinal plants and oxidative stress in the conditions of cold influence. Bulletin physiology and pathology of respiration 2013; 48:76-80 (in russian). Simonova N.V., Lachin A.P, Simonova N.P. Efficiency in correction phytopreparations of lipid peroxidation of biomembranes the background ultraviolet radiation. Vestnik Krasnoyarsk state agrarian University 2010; 5:95-98 (in russian).

Zenkov N.K., Kandalintseva N.V., Lankin V.Z., Men'shchikova E.B., Prosenko A.E.

UDC 591.494(678.048):616-001.18/.19 DOI 10.22448/AMJ.2017.3.27-28

\section{EFFECTIVENESS OF REMAXOL IN THE CORRECTION OF LIPID PEROXIDATION PROCESSES INDUCED BY THE INTRO- DUCTION OF CARBON TETRACHLORIDE}

\author{
V.A. Dorovskikh, N.V. Simonova, E.Yu. Yurtaeva, T.V. Kan, M.A. Shtarberg, V.Yu. Dorovskikh
}

Amur State Medical Academy, Blagoveshchensk, Russia

Summary. At present in the clinical practice compounds of succinic acid having antioxidant and cytoprotective properties are used as pharmacological active substances with a wide range of biological activity. In experimental conditions the possibility to correct free radical lipid oxidation of rats' organism membranes was studied with the introduction of the succinate containing drug called remaxol (Polysan, St.Petersburg). The application of the succinate containing drug called remaxol in the conditions of introduction of carbon tetrachloride of the organism of animals under exper- 
iment leads to the stabilization of the processes of peroxidation against the increase of antioxidant system activity.

Key words: remaxol, carbon tetrachloride, biological membranes lipid peroxidation, products of peroxidation (lipid hydroperoxides, diene conjugates, malonic dialdehyde), antioxidant system.

In connection with the peculiarities of molecular mechanisms of action of carbon tetrachloride on subcellular membranes, the study of the biological action of hepatotropic poison is of interest as a model of the molecular pathology of membrane structures. Carbon tetrachloride causes a dose-dependent liver damage, in addition to exerting a toxic effect on blood cells, connective tissue, morphological and functional state of a number of organs and systems. According to modern concepts, a significant role in the development of pathology in toxic liver play of free radical reactions. Reactive oxygen species cause increased peroxidation of lipids of cellular membranes, contributing to the imbalance between Pro - and antioxidant systems with the subsequent formation of oxidative stress in warm-blooded body, which is pathogenetically justified the appointment of drugs with antioxidant and membrane-protective effect. These properties were detected in medicines containing succinic acid, having broad spectrum of pharmacological activity.

Materials and methods. In experimental conditions the possibility to correct free radical lipid oxidation of rats' organism membranes was studied with the introduction of the succinate containing drug called remaxol (Polysan, St. Petersburg). The animals were divided into 4 groups and each of them had 20 rats: intact animals which were held in standard conditions of vivarium; the control group in which rats intake of the carbon tetrachloride during 3 days daily; the experimental group in which before the introduction of carbon tetrachloride animals had a daily intra-abdominal intake of the remaxol in a dose of $50 \mathrm{mg} / \mathrm{kg}$; the experimental group in which before the introduction of carbon tetrachloride animals had a daily intra-abdominal intake of the remaxol in a dose of $100 \mathrm{mg} / \mathrm{kg}$. The intensity of peroxidation processes was assessed by examining the contents of hydroperoxides lipids, diene conjugates, malonic dialdehyde and the main components of the antioxidant system, (ceruloplasmin, vitamin E) in the plasma of blood animals. The results obtained were subjected to statistical analysis with calculation of parametric criteria Student.

It was found out that in the blood of experimental animals a daily the introduction of carbon tetrachloride during 3 days contributes to the increase of lipid hydroperoxides level (by $20-24 \%$ ), of diene conjugate (by 17 - 19\%), and of malonic dialdehyde (by 51-59\%) against the decrease of antioxidant system activity in the blood of intact animals. The introduction of the succinate containing drug to rats in the conditions of oxidative stress contributes to the reliable decrease in the blood of lipid hydroperoxides by $7-12 \%$, of diene conjugates-by $7-11 \%$, and of malonic dialdehyde by $13-24 \%$ in comparison with the rats of the control group. While analyzing the effect of the succinate containing drug on the activity of the components of antioxidant system it was shown that the level of ceruloplasmin in the blood of animals was reliably higher by $9-24 \%$, of vitamin E by $12-21 \%$, of catalase by $13-24 \%$ in comparison with the same parameters of the rats of the control group.

So, the application of the succinate containing drug called remaxol in the conditions of introduction of carbon tetrachloride of the organism of animals under experiment leads to the stabilization of the processes of peroxidation against the increase of antioxidant system activity.

\section{REFERENCES}

Dorovskikh V.A., Borodin E.A., Lee O.N., Simonova N.V., Starberg M.A., Dorovskikh Yu.V. Comparative efficiency of different antioxidants during cold exposure and overheating. Blagoveshchensk; 2016 (in russian).

Dorovskikh V.A., Borodin E.A., Shtarberg M.A., Shtarberg S.A., Egorov K.E. Phospholipids as antiatherosclerotic drugs. In book: Lipoproteins and atherosclerosis. Abstracts of the Symposium devoted to the 110 anniversary from the birthday of academician N.N. Anichkov «Lipoproteins and atherosclerosis». Moscow; 1995: 41-46 (in russian).

Dorovskikh V.A., Tseluyko S.S., Simonova N.V., Anokhina R.A. In the world of antioxidants. Blagoveshchensk, 2012 (in russian).

Landyshev Ju.S., Dorovskikh V.A., Tseluyko S.S., Lazutkina E.L., Tkacheva S.I., Chaplenko T.N. Bronchial asthma. Blagoveshchensk, 2010 (in russian).

Landyshev Ju.S., Dorovskikh V.A., Chaplenko T.N. Drug Allergy. St-Petersburg, 2010 (in russian).

Simonova I.V., Dorovskikh V.A., Simonova N.V., Shtarberg M.A. Non-specific preventive measures against respiratory diseases of nursery age children. Far Eastern Medical Journal 2009; 3:56-58 (in russian).

Simonova N.V., Dorovskikh V.A., Shtarberg M.A. Effect of adaptogens of plant origin on the intensity of the processes of peroxidation of lipids of membranes under conditions of ultraviolet irradiation. Far Eastern Medical Journal 2010; 2:112-115 (in russian).

Simonova N.V., Dorovskikh V.A., Simonova N.P. Ultraviolet radiation and oxidative stress. The possibility of phitocorrection. Blagoveshchensk, 2014 (in russian).

Simonova N.V., Dorovskikh V.A., Li O.N., Shtarberg M.A., Simonova N.P. Tincture of medicinal plants and oxidative stress in the conditions of cold influence. Bulletin physiology and pathology of respiration 2013; 48:76-80 (in russian).

DOI 10.22448/AMJ.2017.3.28-29

OBSERVATION ON THE THERAPEUTIC EFFECT OF BAILING CAPSULE ON HASHIMOTO ‘S THYROIDITIS

\section{DULikun, ZHOUHaili}

Heilongjiang University of Traditional Chinese Medicine Harbin City, Heilongjiang Province, China

Abstract:Objective:to investigate the clinical efficacy of Bailing Capsule in Hashimoto thyroiditis (HT). Methods:A total of 100 patients who come from the First Affiliated Hospital of Heilongjiang University of Traditional Chines Med- 